\title{
Sympathy Lactation
}

\author{
Deb Gauldin, RN, PMS
}

\begin{abstract}
In this humor column, a childbirth educator describes assisting a parent and her young children with boarding an airplane.
\end{abstract}

The Journal of Perinatal Education, 18(3), 73, doi: 10.1624/105812409X461261

Keywords: humor, childbirth education, let-down reflex, travel

How many times have you stood absolutely still in a grocery store checkout line and watched customers in the next aisle over breezing through, one after another? Counting the number of items per cart can be a predictor of delays, but only a psychic can anticipate and avoid an insufficiently funded debit card or an expired can of croutons.

I am the crouton-equivalent at airport security checkpoints. The passengers who follow me are usually wincing. Into multiple bins go shoes, jewelry, jacket, and purse. The laptop and roller bag follow. Grumbles begin as my guitar case rolls and is usually re-rolled through the screening device. Agents from the Transportation Security Administration know me by name.

As a result, I possess a remarkable ability to analyze and select the fastest screening line. Four businessmen with cell phones and computers move through faster than two elderly men in sneakers - even when taking Velcro closings into account. Three middle-aged women in business attire are speedier than a young couple with multiple piercings, laced boots, and a plethora of electronic devices with an assortment of earbuds.

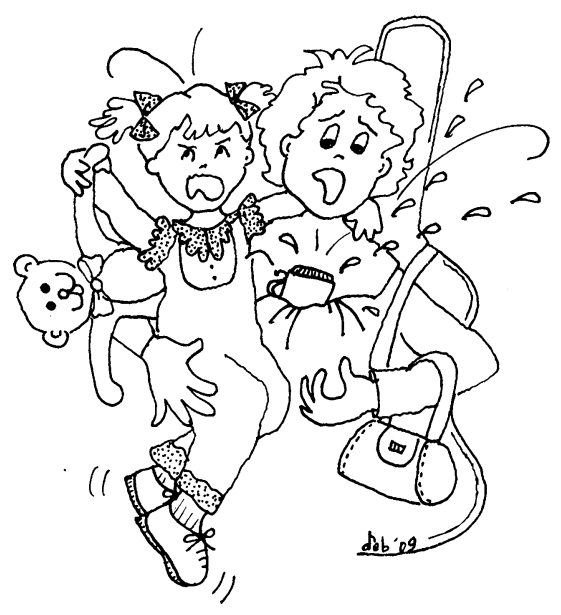

But there is no one I have more patience with or compassion for than a parent traveling alone with small children. On one of my recent travels, I noticed a young mother maneuvering a newborn and inconsolable 19-month-old onto the Jetway ${ }^{\mathrm{TM}}$. The crying had stimulated her let-down reflex, and breastmilk had saturated through both her nursing bra and her blouse. She was juggling several carry-on bags, a booster seat, and a double stroller.

I knew I was an empathetic person, but I had no idea that I would also board the airplane with milk leaking through my blouse. No, I wasn't lactating or even having a hot flash. As I tried to help, the oldest child had dumped a full sippy cup of milk-the lid and all-into my cleavage. By the time I made my connecting flight, I was a little "ripe." But at least my guitar never "lets" me down!

DEB GAULDIN is a childbirth educator who travels nationally presenting keynotes and workshops. Her CDs and tapes contain humor and songs about pregnancy, childbirth, and the adjustment to parenthood. For booking information or to purchase Deb's recordings, call 800-682-2347 or visit her Web site (www.debgauldin.com). 